\title{
Pengaruh Solvabiltas dan Profitabilitas Terhadap Harga Saham Perusahaan Jasa Sub Sektor Kontruksi Bangunan yang terdaftar di Bursa Efek Indonesia Periode 2012-2017
}

\author{
Ellena Ratna Pujiarti ${ }^{1}$, Ima Kristina Yulita ${ }^{2}$ \\ Ninjaxpress Jakarta ${ }^{1}$ \\ Program Studi Manajemen, Fakultas Ekonomi, Universitas Sanata Dharma Yogyakarta ${ }^{2}$ \\ ellenaratnap@gmail.com ${ }^{1}$, yulitaimakristina@gmail.com ${ }^{2}$
}

DOI: $\underline{\text { https://doi.org/10.24071/exero.v3i1.4239 }}$

\begin{abstract}
Abstrak
Penelitian ini bertujuan mengetahui pengaruh solvabilitas dan profitabilitas terhadap harga saham perusahaan jasa subsektor konstruksi bangunan. Sampel dalam penelitian ini sebanyak enam perusahaan yang terdaftar di Bursa Efek Indonesia dalam kurun waktu 2012-2017. Metode pengambilan sampel yang digunakan adalah purposive sampling. Data yang digunakan adalah data sekunder yang dikumpulkan dengan metode dokumentasi. Berdasarkan hasil uji hipotesis menggunakan regresi data panel, diketahui bahwa solvabilitas dan profitabilitas secara parsial berpengaruh terhadap harga saham.
\end{abstract}

Kata kunci : solvabilitas, profitabilitas, harga saham

\section{Abstract}

The purpose of this research is to find out the influence of solvability and profitability on the stock price of building construction. The sample of this research includes six companies listed in BEI in the period from 2012 to 2017. This sampling method used in this research is purposive sampling. The data consists of secondary data collected using the documentation method. The result shows that partially solvability and profitability had significant influence on the stock prices.

Keywords: solvability, profitability, stock price

\section{Pendahuluan}

Saat ini ada banyak cara yang dapat dilakukan untuk menyimpan uang, salah satunya dengan berinvestasi. Investasi adalah penanaman modal yang dilakukan investor, baik investor asing maupun domestik dalam berbagai bidang usaha yang terbuka untuk investasi, yang bertujuan untuk memperoleh keuntungan. Adapun keuntungan yang bisa diperoleh dengan melakukan investasi antara lain kebebasan finansial, menghindari inflasi dan untuk menyiapkan pension.

Investasi juga dapat dilakukan dengan membeli surat berharga di pasar modal seperti saham dan obligasi. Menurut Undang-Undang Pasar Modal No. 8 (1995), pihak yang menyelenggarakan dan menyediakan sistem dan atau sarana untuk mempertemukan penawaran jual dan beli efek (saham dan obligasi) pihak-pihak lain dengan tujuan memperdagangkan efek (saham dan obligasi) diantara mereka disebut 
Bursa Efek. Bursa Efek Indonesia atau BEI mengklasifikasikan perusahaanperusahaan publik yang mencatatkan sahamnya ke dalam sembilan sektor. Salah satu sektor diantaranya adalah sektor jasa, seperti properti, real estate, dan konstruksi bangunan. Sektor tersebut dibagi lagi menjadi dua sub sektor, salah satunya yaitu sub sektor konstruksi bangunan.

Pada tahun 2016 sektor konstruksi berada di posisi ketiga sebagai sumber pertumbuhan ekonomi di Indonesia dengan kontribusi 0,51\%. Berdasarkan data Badan Pusat Statistik (BPS), ekonomi Indonesia pada tahun 2016 tumbuh sebesar 5,02\%, lebih tinggi dibandingkan tahun 2015 sebesar 4,88\%. Kontribusi sektor konstruksi bagi pembentukan Produk Domestik Bruto (PDB) pun cukup signifikan, yakni 10,38\%. Menurut Menteri Pekerjaan Umum dan Perumahan Rakyat (PUPR) Basuki Hadimuljono, pembangunan infrastruktur yang berasal dari sektor konstruksi selain menggerakkan ekonomi riil, juga ikut menyumbang pada pertumbuhan ekonomi negara Indonesia dengan menyerap tenaga kerja dalam jumlah yang cukup besar dan pembangunan infrastruktur pada tahun 2017 masih menjadi salah satu tumpuan untuk mencapai target pertumbuhan ekonomi sebesar 5,2\% hingga 5,4\% dan pemerataan kesejahteraan secara nasional (Purnomo, 2017). Keadaan ini mendorong sektor konstruksi bangunan terus berkembang sehingga para investor tertarik untuk menanamkan modal mereka. Dalam menanamkan modalnya, investor harus mengetahui informasi mengenai harga saham perusahaan yang akan dipilih. Informasi harga saham ini penting untuk melihat apakah investor akan membuat keputusan untuk menanamkan modalnya dengan melihat dana yang dimiliki atau dengan melihat target keuntungan yang akan dicapai.

Menurut Sartono (2008) harga saham terbentuk melalui mekanisme permintaan dan penawaran di pasar modal. Apabila suatu saham mengalami kelebihan permintaan, maka harga saham cenderung naik. Sebaliknya, apabila mengalami kelebihan penawaran maka harga saham cenderung turun. Permintaan dan penawaran didasarkan pada seberapa jauh manajemen telah berhasil mengelola perusahaan atas nama pemegang saham. Dengan demikian, pengambilan keputusan selalu didasarkan pada pertimbangan terhadap maksimalisasi kekayaan para pemegang saham. Fahmi (2014, p. 329) menyatakan bahwa terdapat tujuh faktor yang mempengaruhi harga saham yaitu kondisi mikro dan makro ekonomi, kebijakan 
perusahaan, adanya direksi atau pihak komisaris perusahaan yang terlibat pidana dan kasusnya telah masuk pengadilan, kinerja perusahaan dan manajemen, risiko sistematik, dan efek psikologi pasar yang mampu menekan kondisi teknikal dalam jual beli saham. Penelitian ini hanya akan menggunakan factor kinerja perusahaan dan manajemen.

Kinerja perusahaan dan kekuatan manajemen mencerminkan harga saham suatu perusahaan. Kinerja perusahaan dijadikan acuan bagi para investor maupun analis fundamental dalam melakukan pengkajian terhadap saham perusahaan. Analisis fundamental adalah analisis sekuritas yang menggunakan data fundamental yang berhubungan dengan perusahaan/ badan usaha. Data fundamental yang dimaksud seperti data dari laporan keuangan. Laporan keuangan yang dianalisis adalah laporan keuangan yang berasal dari neraca dan laporan laba-rugi. Investor dapat menggunakan data dari laporan tersebut untuk mengetahui kinerja perusahaan dan kekuatan manajemen yang dihitung menggunakan rasio keuangan.

Menurut Samsul (2015, p. 174) apabila ingin mengetahui kekuatan manajemen, maka rasio likuiditas, rasio aktivitas, dan rasio solvabilitas harus dianalisis, dan jika ingin menilai kinerja perusahaan, maka rasio profitabilitas dan tren harus diperhatikan. Rasio yang digunakan dalam penelitian ini adalah rasio solvabilitas dan rasio profitabilitas. Hal ini karena elemen kunci profitabilitas adalah laba atau kemampuan menghasilkan laba, yang menunjukkan kemampuan berulang untuk menghasilkan kas dari operasi. Ukuran berbasis laba merupakan indikator penting dan dapat diandalkan terkait kekuatan keuangan. Laba merupakan sumber kas yang paling diinginkan dan diandalkan untuk pembayaran jangka panjang atas bunga dan pokok hutang. Sedangkan rasio solvabilitas atau leverage ratio merupakan rasio yang digunakan untuk mengukur sejauh mana aktiva perusahaan dibiayai dengan utang (Kasmir, 2012, p. 151). Artinya berapa besar beban utang yang ditanggung perusahaan dibandingkan dengan aktivanya. Rasio yang digunakan dalam menganalisis solvabilitas antara lain Debt to Equity Ratio (DER) dan Debt to Total Assets Ratio (DAR). Rasio solvabilitas mempermudah manajemen dan investor untuk memahami tingkat risiko struktur modal pada perusahaan melalui catatan atas laporan keuangan.

Analisis solvabilitas melibatkan beberapa elemen utama, analisis struktur 
modal adalah salah satunya. Struktur modal merujuk pada sumber pendanaan perusahaan. Pendanaan dapat berasal dari modal ekuitas yang relatif permanen hingga sumber pendanaan jangka pendek yang lebih temporer dan berisiko. Menurut Subramanyam (2017, p. 161), setelah perusahaan memperoleh pendanaan maka perusahaan akan menginvestasikannya pada berbagai aset. Oleh karena itu, penelitian ini memakai rasio Debt to Assets Ratio (DAR). DAR adalah rasio yang dihitung dengan membagi total hutang (jangka panjang dan jangka pendek) dengan total aset. Rasio ini digunakan untuk mengukur seberapa banyak aset yang dibiayai oleh hutang. Wira (2011, p. 75) menyatakan bahwa semakin rendah nilai rasio ini, biasanya akan semakin baik. Umumnya nilai rasio DAR lebih besar dari 1 dihindari karena apabila kreditor menagih maka perusahaan yang ditagih tidak akan mampu melunasi utang walaupun semua assetnya dijual. Maka dari itu, sebaiknya investor memperhatikan Debt to Assets Ratio (DAR). Semakin kecil rasio ini maka semakin baik dan sebaliknya semakin besar rasio ini akan berdampak pada harga saham perusahaan dimana akan mempengaruhi permintaan saham perusahaaan tersebut. Hal ini tentu akan merugikan perusahaan sebab investor akan menilai manajemen lemah dalam mengelola perusahaan sehingga akan menyebabkan harga saham perusahaan turun.

Apabila ingin menilai kinerja perusahaan dapat dilakukan dengan menggunakan rasio profitabilitas. Rasio profitabilitas digunakan untuk mengevaluasi kemampuan/kinerja perusahaan dalam menghasilkan laba. Rasio profitabilitas yang sering digunakan antara lain: Net Profit Margin (NPM), Return of Sales, Return On Equity (ROE) dan Return On Assets (ROA). Rasio profitabilitas yang digunakan dalam penelitian ini adalah Net Profit Margin (NPM). NPM adalah rasio yang didapat dari membagi keuntungan bersih dengan total penjualan. Rasio ini menunjukkan tingkat keuntungan bersih yang dapat diperoleh dari setiap rupiah penjualan. Wira (2011, p. 71), menyebutkan bahwa semakin besar nilai rasio ini semakin baik karena menunjukkan perusahaan sangat menguntungkan. Pada prinsipnya semakin menguntungkan perusahaan tersebut maka akan meningkatkan permintaan saham perusahaaan tersebut sehingga pada gilirannya akan meningkatkan pula harga saham perusahaan. Penelitian sebelumnya oleh Manoppo (2017) menemukan bahwa NPM berpengaruh negatif terhadap harga saham sedangkan 
Hutami (2012) dan Wangarry et al. (2016) menemukan bahwa NPM berpengaruh positif terhadap harga saham.

Berdasarkan uraian tersebut, penelitian bertujuan menguji pengaruh solvabilitas dan profitabilitas terhadap harga saham secara parsial pada perusahaan jasa sub sektor konstruksi bangunan yang terdaftar di Bursa Efek Indonesia periode 2012-2017’.

\section{Kajian Literatur}

\section{Profitabilitas}

Profitabilitas atau rentabilitas adalah kemampuan perusahaan dalam menghasilkan laba (Prihadi, 2013, p. 138). Rentabilitas perusahaan menunjukkan perbandingan antara laba dengan aktiva atau modal. Semakin tinggi profitabilitas suatu perusahaan maka semakin tinggi pula kemampuan perusahaan tersebut dalam menghasilkan laba. Profitabilitas juga merupakan suatu indikator kinerja yang dilakukan manajemen dalam mengelola kekayaan perusahaan yang ditunjukkan dengan laba yang dihasilkan.

\section{Rasio Profitabilitas}

Rasio ini mengukur efektivitas manajemen secara keseluruhan yang ditunjukkan oleh besar kecilnya tingkat keuntungan yang diperoleh dalam hubungannya dengan penjualan maupun investasi (Fahmi, 2013, p. 135). Semakin besar rasio profitabilitas maka menggambarkan semakin tinggi kemampuan perusahaan dalam perolehan keuntungannya. Menurut Kasmir (2012, p. 196), rasio profitabilitas digunakan untuk menilai kemampuan perusahaan dalam mencari keuntungan. Rasio ini juga memberikan ukuran tingkat efektivitas manajemen suatu perusahaan. Hal ini ditunjukkan oleh laba yang dihasilkan dari penjualan dan pendapatan investasi. Penggunaan hasil perhitungan rasio profitabilitas menunjukkan efisiensi perusahaan.

Perhitungan rasio profitabilitas dapat dilakukan dengan membandingkan antara berbagai komponen yang ada di laporan keuangan, terutama laporan keuangan neraca dan laba rugi. Pengukuran dapat dilakukan untuk beberapa periode agar terlihat perkembangan perusahaan dalam rentang waktu tertentu, baik penurunan atau kenaikan, sekaligus mencari penyebab terjadinya perubahan atau perbedaan dari hasil perhitungan rasio profitabilitas perusahaan pada setiap periode waktu yang 
sudah ditentukan. Hasil pengukuran tersebut dapat dijadikan sebagai alat evaluasi kinerja manajemen terkait pencapaian target yang sudah ditetapkan oleh perusahaan. Jika berhasil, mereka dikatakan sudah mencapai target untuk periode atau beberapa periode. Namun, sebaliknya jika gagal atau tidak berhasil mencapai target yang telah ditentukan, ini akan menjadi pelajaran bagi manajemen untuk periode ke depan. Oleh karena itu, rasio ini sering disebut sebagai salah satu alat ukur kinerja manajemen.

Rasio profitabilitas atau rasio rentabilitas terdiri atas:

\section{Net Profit Margin (NPM)}

Net profit margin mengukur laba setelah mempertimbangkan seluruh pendapatan dan beban, termasuk beban bunga, beban non operasi dan pajak penghasilan (Fraser, 2001, p. 188). Menurut Prihadi (2013, p. 147) net profit margin ratio (laba bersih) mengukur kemampuan perusahaan dalam rangka memberikan return kepada pemegang saham. Sedangkan, menurut Wardiyah (2017, p. 142) net profit margin merupakan rasio yang digunakan untuk mengukur laba bersih setelah pajak lalu dibandingkan dengan volume penjualan. Rumus untuk mencari Net Margin Ratio (NPM) adalah sebagai berikut:

$$
\text { Net Margin Ratio }=\frac{\text { Laba Bersih }}{\text { Penjwalan }}
$$

\section{Return on Total Asset (ROA)}

Return on Total Asset (ROA) digunakan untuk melihat sejauh mana investasi yang telah ditanamkan mampu memberikan pengembalian keuntungan sesuai dengan yang diharapkan. Semakin tinggi angka ROA mengindikasikan bahwa investasi yang telah ditanamkan oleh investor memberikan pengembalian keuntungan yang tinggi, dan sebaliknya. Adapun rumus Return on Total Asset (ROA) sebagai berikut:

Return on Assets $=\frac{\text { Earning After } T A x(E A T)}{}$

Total Assets

\section{Return on Equity (ROE)}

Return on Equity disebut juga dengan laba atas equity. Rasio ini mengkaji sejauh mana suatu perusahaan mempergunakan sumber daya yang dimiliki untuk mampu memberikan laba atas ekuitas. ROE digunakan untuk mengetahui besarnya 
pengembalian terhadap investasi para pemegang saham. Angka dari ROE akan menunjukkan seberapa jauh kinerja perusahaan dalam memanfaatkan investasi para pemegang saham. Semakin tinggi angka ROE mengindikasikan semakin tinggi tingkat pengembalian yang akan diterima investor. Adapun rumus return on equity sebagai berikut:

$$
\text { Return on Equity }=\frac{\text { Earning After } T A x(E A T)}{\text { Shareholders Equity }}
$$

\section{Tujuan Dan Manfaat Rasio Profitabilitas}

Rasio profitabilitas memiliki tujuan dan manfaat, tidak hanya bagi pihak pemilik usaha atau manajemen saja, tetapi juga bagi pihak di luar perusahaan terutama pihakpihak yang memiliki hubungan atau kepentingan dengan perusahaan.

Menurut Kasmir (2012, p. 197) tujuan penggunaan rasio profitabilitas bagi perusahaan maupun pihak luar perusahaan yaitu:

1. Untuk mengukur atau menghitung laba yang diperoleh perusahaan dalam satu periode tertentu.

2. Untuk membandingkan laba perusahaan tahun sebelumnya dengan tahun sekarang.

3. Untuk menilai besarnya laba bersih sesudah pajak dengan modal sendiri

\section{Solvabilitas}

Solvabilitas menggambarkan kemampuan perusahaan dalam membayar kewajiban jangka panjangnya (Wardiyah, 2017, p. 165). Menurut Fahmi (2013, p. 174), solvabilitas adalah gambaran kemampuan suatu perusahaan dalam memenuhi dan menjaga kemampuannya untuk selalu mampu memenuhi kewajibannya dalam membayar utang secara tepat waktu.

\section{Rasio solvabilitas}

Rasio solvabilitas atau leverage ratio merupakan rasio yang digunakan untuk mengukur sejauh mana aktiva perusahaan dibiayai dengan utang (Kasmir, 2012, p. 151). Artinya berapa besar beban utang yang ditanggung perusahaan dibandingkan dengan aktivanya. Dalam arti luas dikatakan bahwa rasio solvabilitas digunakan untuk mengukur kemampuan perusahaan untuk membayar seluruh kewajibannya, 
baik jangka pendek maupun jangka panjang apabila perusahaan dibubarkan (dilikuidasi).

Macam-macam rasio solvabilitas atau rasio leverage sebagai berikut:

\section{Debt to Asset Ratio (DAR)}

Debt to Asset Ratio merupakan rasio utang yang digunakan untuk mengukur perbandingan antara total utang dengan total aktiva (Kasmir, 2012, p. 156). Dengan kata lain, seberapa besar aktiva perusahaan dibiayai oleh utang atau seberapa besar utang perusahaan berpengaruh terhadap pengelolaan aktiva. Apabila angka DAR diatas $100 \%$ maka rasionya tinggi, artinya pendanaan dengan utang semakin banyak, maka semakin sulit bagi perusahaan untuk memperoleh tambahan pinjaman karena dikhawatirkan perusahaan tidak mampu menutupi utang-utangnya dengan aktiva yang dimilikinya. Oleh karena itu, angka rasio DAR > 100\% harus dihindari oleh investor. Investor harus memilih perusahaan yang memiliki angka rasio sebesar < $100 \%$, sebab semakin sedikit aset perusahaan yang dibiayai dengan utang. Rumus untuk mencari Debt to Asset Ratio (DAR) adalah sebagai berikut:

$$
\text { Debt to Asset Ratio }=\frac{\text { Total Debt }}{\text { Total Assets }}
$$

\section{Debt to Equity Ratio (DER)}

Siegel dan Shim dalam Fahmi (2011, p. 128) mendefinisikan DER sebagai "Ukuran yang dipakai dalam menganalisis laporan keuangan untuk memperlihatkan besarnya jaminan yang tersedia untuk kreditor". DER digunakan untuk menunjukkan sejauh mana modal perusahaan dibiayai oleh hutang. Semakin tinggi angka DER mengindikasikan bahwa semakin rendah pendanaan perusahaan yang biayai oleh perusahaan, dan sebaliknya. Bagi perusahaan sebaiknya, besarnya hutang tidak boleh melebihi modal sendiri agar beban tetapnya tidak terlalu tinggi. Semakin kecil angka rasio DER semakin baik.

Graham dalam Sitorus dan Hutasoit (2017, p. 18) berpendapat bahwa debt equity ratio untuk perusahaan industri diluar dari perusahaan utiliti dan telekomunikasi tidak boleh lebih 100\% sehingga jumlah hutang jangka panjang dan hutang jangka pendek tidak boleh melebihi ekuitas. Angka DER > 100\% harus dihindari oleh investor dan angka DER yang $<100 \%$ harus dipilih oleh investor 
apabila ingin berinvestasi dalam suatu perusahaan. Adapun rumus Debt to Equity Ratio adalah sebagai berikut :

$$
\text { Debt to Equity Ratio }=\frac{\text { Total Liabilities }}{\text { Total Shareholders's Equity }}
$$

\section{Tujuan Rasio Solvabilitas}

Perusahaan dalam memilih menggunakan modal sendiri atau modal pinjaman haruslah menggunakan beberapa perhitungan. Hal ini karena penggunaan modal sendiri atau modal pinjaman akan memberikan dampak tertentu bagi perusahaan. Pihak manajemen harus mampu mengatur angka rasio, sebab semakin kecil rasio solvabilitas akan memberikan banyak manfaat bagi perusahaan guna menghadapi segala kemungkinan yang akan terjadi.

Berikut adalah beberapa tujuan perusahaan menggunakan rasio solvabilitas menurut Kasmir (2012, pp. 153-154) yaitu:

1. Untuk mengetahui posisi perusahaan terhadap kewajiban kepada pihak lainnya (kreditor).

2. Untuk menilai kemampuan perusahaan dalam memenuhi kewajiban yang bersifat tetap (seperti angsuran pinjaman termasuk bunga).

3. Untuk menilai keseimbangan antara nilai aktiva khususnya aktiva tetap dengan modal.

4. Untuk menilai seberapa besar aktiva perusahaan dibiayai oleh utang.

5. Untuk menilai seberapa besar pengaruh utang perusahaan terhadap pengelolaan aktiva.

\section{Pandangan Investor tentang Rasio Keuangan}

Chen dan Shimerda (1981) dalam Fahmi (2013, p. 115) menyatakan bahwa rasio keuangan merupakan bagian penting dalam mengevaluasi kinerja dan kondisi keuangan dari suatu entitas sehingga rasio keuangan yang dianalisis adalah yang dianggap secara teoritis dan disesuaikan dengan bukti empiris yang diperoleh serta dihubungkan dengan untuk apa rasio keuangan tersebut dipergunakan dan ditujukan. Rasio keuangan dipergunakan oleh pihak manajemen perusahaan untuk membandingkan rasio pada saat sekarang dengan rasio pada saat yang akan datang. 
Adapun bagi investor adalah membandingkan rasio keuangan satu perusahaan/industri dengan perusahaan/industri lain yang sejenis dengan maksud nantinya akan bisa memberikan suatu analisis perbandingan yang memperlihatkan perbedaan dalam kinerja keuangan. Investor mempergunakan rasio keuangan sebagai bagian untuk menganalisis perusahaan dengan cara membandingkan rasio keuangan satu perusahaan dengan perusahaan lain yang sejenis dengan harapan cara ini akan memberi kemudahan dan kecepatan dalam proses pengambilan keputusan.

\section{Perumusan Hipotesis}

Rasio solvabilitas merupakan rasio yang digunakan untuk mengukur sejauh mana aktiva perusahaan dibiayai dengan utang. Rasio solvabilitas yang digunakan dalam penelitian ini adalah Debt to Total Assets Ratio (DAR). DAR adalah rasio yang dihitung dengan membagi total hutang (jangka panjang dan jangka pendek) dengan total aset. Rasio ini digunakan untuk mengukur seberapa banyak aset yang dibiayai oleh hutang. Dengan adanya analisis rasio ini, akan terlihat kemampuan manajemen dalam menjalankan tugas operasinya. Tinggi atau rendahnya angka rasio DAR akan mempengaruhi harga saham suatu perusahaan di bursa efek. Semakin tinggi angka atau hasil rasio DAR menandakan semakin banyak aset perusahaan dibiayai oleh utang atau semakin buruk kemampuan manajemen dalam menjalankan operasi perusahaan. Angka DAR yang semakin tinggi memberikan indikasi bagi para pemegang saham bahwa tingkat pengembalian investasi semakin kecil. Apabila rasio solvabilitas yang dihitung menggunakan DAR memiliki angka yang kecil maka menandakan bahwa investor semakin tertarik untuk menanamkan modalnya di perusahaan tersebut sehingga membuat harga saham meningkat.

Rasio profitabilitas digunakan untuk mengevaluasi kemampuan/kinerja perusahaan dalam menghasilkan laba. Rasio profitabilitas yang digunakan dalam penelitian ini adalah Net Profit Margin (NPM). NPM adalah rasio yang didapat dari membagi keuntungan bersih dengan total penjualan. Rasio ini menunjukkan tingkat keuntungan bersih yang dapat diperoleh dari setiap rupiah penjualan. Dengan adanya analisis rasio ini, akan terlihat kinerja perusahaan dalam menjalankan operasinya. Semakin tinggi angka rasio NPM menandakan bahwa semakin tinggi pula kemampan perusahaan dalam menghasilkan laba dan semakin baik kinerja 
perusahaan. Apabila rasio profitabilitas dihitung menggunakan NPM memiliki angka yang tinggi memberikan indikasi bagi para pemegang saham bahwa tingkat pengembalian investasi semakin besar dan semakin banyak investor akan tertarik untuk menanamkan modalnya di perusahaan tersebut. Menurut Suwandani et al (2017), net profit margin berpengaruh terhadap harga saham. Penelitian sebelumnya oleh Manoppo et al. (2017) menemukan bahwa NPM berpengaruh negatif terhadap harga saham sedangkan Hutami (2012) menemukan bahwa NPM berpengaruh positif terhadap harga saham.

Berdasarkan uraian tersebut, maka peneliti merumuskan hipotesisnya sebagai berikut:

H1: Solvabilitas secara parsial berpengaruh terhadap harga saham.

H2: Profitabilitas secara parsial berpengaruh terhadap harga saham.

\section{Kerangka konseptual}

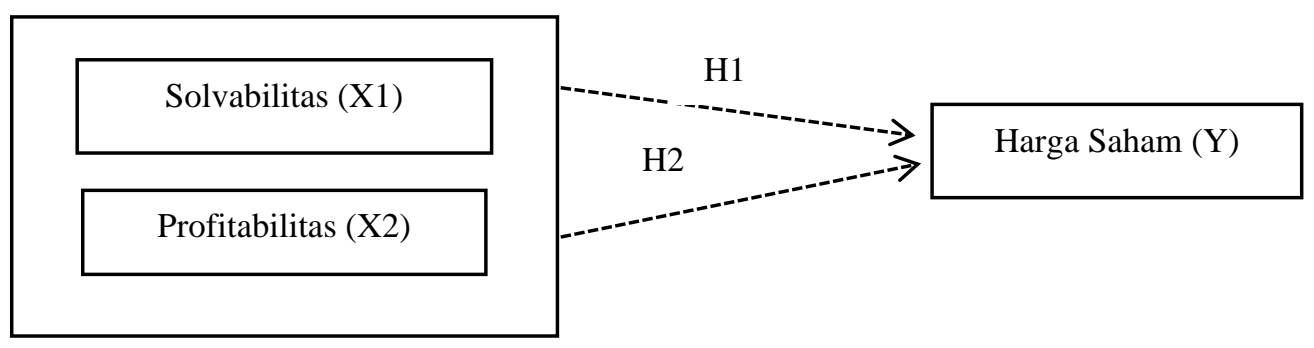

Gambar 1. Kerangka konseptual penelitian

\section{Metode Penelitian}

Jenis penelitian ini adalah penelitian kausalitas yang bertujuan untuk meneliti kemungkinan adanya hubungan sebab-akibat antar variabel (Sanusi, 2011, p. 14), namun tidak melalui eksperimen melainkan dengan pengamatan terhadap data dari faktor yang diduga menjadi penyebab. Pengumpulan data dilakukan pada bulan Februari 2019.

Penelitian ini memakai variabel bebas dan variable terikat. Variabel bebasnya yaitu solvabilitas yang diproksi dengan rasio Debt to Asset Ratio (DAR) dan profitabilitas yang diproksi dengan rasio Net Profit Margin (NPM). Debt to Asset Ratio merupakan rasio utang yang digunakan untuk mengukur perbandingan antara 
total utang dengan total aktiva (Kasmir, 2012, p. 156). Rumus untuk mencari Debt to Asset Ratio (DAR) adalah sebagai berikut:

Debt to Asset Ratio $=\frac{\text { Total Debt }}{\text { Total Assets }}$

Net profit margin ratio Menurut Prihadi (2013, p. 147) mengukur kemampuan perusahaan dalam rangka memberikan return kepada pemegang saham. Sedangkan, menurut Wardiyah (2017, p. 142) net profit margin merupakan rasio yang digunakan untuk mengukur laba bersih setelah pajak lalu dibandingkan dengan volume penjualan. Rumus untuk mencari Net Margin Ratio (NPM) adalah sebagai berikut:

$$
\text { Net Margin Ratio }=\frac{\text { Laba Bersih }}{\text { Penjwalan }}
$$

Variabel bebas yang digunakan adalah harga saham. Harga saham yang digunakan adalah harga penutupan.

Populasi dari penelitian ini adalah 16 perusahaan jasa sub sektor konstruksi bangunan yang tergabung dalam Bursa Efek Indonesia. Sampel diambil dengan metode purposive sampling. Pertimbangan yang digunakan dalam mengambil sampel yaitu perusahaan jasa sub sektor konstruksi bangunan yang terdaftar di Bursa Efek Indonesia, melakukan go public selambat-lambatnya tahun 2010 dan mempublikasikan laporan keuangan perusahaan selama periode tahun 2012-2017. Terdapat enam perusahaan yang memenuhi kriteria tersebut yaitu PT Adhi Karya Tbk (ADHI), PT Nusa Konstruksi Enjiniring Tbk (DGIK), PT Pembangunan Perusahaan Tbk (PTPP), PT Surya Semesta Internusa Tbk (SSIA), PT Total Bangun Persada Tbk (TOTL), dan PT Wijaya Karya Tbk (WIKA).

Penelitian ini menggunakan data sekunder yang dikumpulkan dengan cara dokumentasi. Data sekunder adalah data yang sudah tersedia dan dikumpulkan oleh pihak-pihak lain (Sanusi, 2011, p. 104). Data tersebut berupa harga saham, data DAR dan NPM yang diperoleh dari situs resmi Bursa Efek Indonesia yaitu www.idx.co.id dan www.idnfinancials.com.

Teknik analisis data yang digunakan adalah Regresi Data Panel. Estimasi model regresi dengan data panel memakai metode Koefisien Tetap Antar Waktu dan Individu (Common Effect). Metode ini dipilih karena penelitian ini menggabungkan data time series dan cross section tanpa melihat perbedaan antar waktu dan individu 
(Widarjono, 2007, p. 251). Adapun persamaan regresi data panel yang digunakan sebagai berikut :

$\mathrm{Y}_{\mathrm{it}}=\alpha+\mathrm{b}_{1} \mathrm{X}_{1 \mathrm{it}}+\mathrm{b}_{2} \mathrm{X}_{2 \mathrm{it}}+\mathrm{e}$

dimana:

$\mathrm{Y}=$ Harga Saham

$\alpha=$ Konstanta

$\mathrm{X}_{1}=$ Solvabilitas

$\mathrm{X}_{2}=$ Profitabilitas

$b_{1}, b_{2}=$ Koefisien regresi masing-masing variabel independen

$\mathrm{e}=$ Error term

$\mathrm{t}=$ Waktu

$\mathrm{i}=$ Perusahaan

\section{Hasil Dan Pembahasan}

\section{Deskriptif Statistik Variabel}

\section{Debt to Asset Ratio (DAR)}

Debt to Asset Ratio digunakan untuk mengukur perbandingan antara total utang dengan total aset (Kasmir, 2012, p. 156). Apabila angka DAR lebih dari 100\% berarti asset perusahaan didanai dengan utang sehingga perusahaan akan semakin sulit untuk memperoleh tambahan pinjaman karena dikhawatirkan perusahaan tidak mampu menutupi utang-utangnya dengan aset yang dimilikinya. Investor sebaiknya memilih perusahaan yang memiliki angka rasio DAR $<100 \%$, sebab semakin sedikit aset perusahaan yang dibiayai dengan utang. Tabel 1 berikut merupakan data Debt to Asset Ratio selama masa penelitian:

Tabel 1. Rekapitulasi Data Debt to Asset Ratio tahun 2012-2017

\begin{tabular}{|c|c|c|c|c|c|c|c|c|}
\hline \multirow{2}{*}{ No } & \multirow{2}{*}{ Kode } & \multicolumn{6}{|c|}{ Debt to Asset Ratio (\%) } & \multirow{2}{*}{$\begin{array}{c}\text { Rata- } \\
\text { rata }\end{array}$} \\
\hline & & 2012 & 2013 & 2014 & 2015 & 2016 & 2017 & \\
\hline 1 & ADHI & 85 & 84,07 & 83,25 & 69,2 & 72,9 & 79,2 & 78,94 \\
\hline 2 & DGIK & 42,7 & 49,53 & 45,98 & 48,24 & 51,21 & 56,81 & 49,08 \\
\hline 3 & PTPP & 80,63 & 84 & 83,64 & 73,24 & 65,43 & 65,91 & 75,47 \\
\hline 4 & SSIA & 65,61 & 55,08 & 49,29 & 48,36 & 53,4 & 49,42 & 53,53 \\
\hline 5 & TOTL & 65,8 & 63,21 & 67,82 & 69,56 & 68,05 & 68,85 & 67,21 \\
\hline 6 & WIKA & 74,29 & 74,38 & 68,72 & 72,26 & 59,81 & 67,97 & 69,57 \\
\hline
\end{tabular}

Sumber: Data sekunder diolah (2019) 
Berdasarkan tabel 1, ADHI memiliki DAR tertinggi sebesar 85\% pada tahun 2012 dan juga rata-rata DAR tertinggi selama tahun 2021-2017 yaitu 78,94\%. Hal ini berarti ADHI memiliki rata-rata perbandingan total utang dengan total asset yang lebih tinggi dibandingkan dengan lima perusahaan lainnya. Sedangkan nilai DAR terendah sebesar 42,7\% terjadi pada tahun 20212 dan rata-rata DAR terendah selama periode enam tahun sebesar 49,08\% dimiliki oleh DGIK.

\section{Net Profit Margin (NPM)}

Menurut Prihadi (2013, p. 147), net profit margin ratio (laba bersih) mengukur kemampuan perusahaan dalam rangka memberikan pengembalian kepada pemegang saham. Semakin besar NPM menunjukkan semakin besar pula kemampuan perusahaan untuk menghasilkan laba. Margin laba yang tinggi lebih disukai karena menunjukkan bahwa perusahaan mendapatkan hasil yang baik yang melebihi harga pokok penjualan. Berikut ini merupakan data Net Profit Margin selama masa penelitian:

Tabel 2. Rekapitulasi Data Net Profit Margin tahun 2012-2017

\begin{tabular}{ccccccccc}
\hline \multirow{2}{*}{ No } & \multirow{2}{*}{ Kode } & & \multicolumn{9}{c}{ Net Profir Margin (\%) } & & \multirow{2}{*}{ Rata-rata } \\
\cline { 3 - 7 } & & $\mathbf{2 0 1 2}$ & $\mathbf{2 0 1 3}$ & $\mathbf{2 0 1 4}$ & $\mathbf{2 0 1 5}$ & $\mathbf{2 0 1 6}$ & $\mathbf{2 0 1 7}$ & \\
\hline 1 & ADHI & 2,78 & 4,17 & 3,77 & 4,95 & 2,85 & 3,41 & 3,65 \\
\hline 2 & DGIK & 3,9 & 4,55 & 3,02 & 0,3 & $-34,9$ & 1,28 & $-3,64$ \\
\hline 3 & PTPP & 3,87 & 3,61 & 4,28 & 5,95 & 7 & 8,02 & 5,45 \\
\hline 4 & SSIA & 20,72 & 16,29 & 11,5 & 7,87 & 2,65 & 3,79 & 10,47 \\
\hline 5 & TOTL & 9,9 & 9,32 & 7,77 & 8,44 & 9,3 & 7,88 & 8,77 \\
\hline 6 & WIKA & 5,15 & 5,25 & 6,02 & 5,2 & 7,32 & 5,2 & 5,69 \\
\hline
\end{tabular}

Sumber: Data sekunder diolah (2019)

Berdasarkan tabel 2, NPM yang paling tinggi dimiliki oleh SSIA pada tahun 2012 sebesar 20,72\%. Rata-rata NPM tertinggi selama tahun 2012-2017 juga dimiliki oleh SSIA sebesar 10,47\%. NPM terendah dimiliki oleh DGIK sebesar $-34,9 \%$ dan ratarata NPM terendah selama enam tahun juga dimiliki oleh DGIK -3,64\%. Hal ini berarti SSIA memiliki kemampuan laba yang paling besar dibanding lima perusahaan lainnya. 


\section{Harga saham}

Harga saham terjadi di pasar bursa pada saat tertentu yang ditentukan oleh pelaku pasar dan permintaan dan penawaran saham yang bersangkutan di pasar modal. Semakin tinggi harga saham menandakan prospek perusahaan yang baik. Harga saham yang digunakan dalam penelitian ini adalah merupakan harga saham pada saat penutupan. Berikut ini merupakan data harga saham perusahaan-perusahaan selama masa penelitian:

Tabel 3. Rekapitulasi Data Harga Saham tahun 2012-2017

\begin{tabular}{|c|c|c|c|c|c|c|c|}
\hline \multirow{2}{*}{ No } & \multirow{2}{*}{ Kode } & \multicolumn{6}{|c|}{ Harga Saham (Rp) } \\
\hline & & 2012 & 2013 & 2014 & 2015 & 2016 & 2017 \\
\hline 1 & ADHI & 1.493 & 1.281 & 2.953 & 2.140 & 2.080 & 1.885 \\
\hline 2 & DGIK & 144 & 150 & 179 & 85 & 55 & 58 \\
\hline 3 & PTPP & 830 & 1.160 & 3.575 & 3.875 & 3.810 & 2.640 \\
\hline 4 & SSIA & 1.080 & 560 & 1.070 & 715 & 434 & 515 \\
\hline 5 & TOTL & 900 & 500 & 1.120 & 615 & 765 & 660 \\
\hline 6 & WIKA & 1.480 & 1.580 & 3.680 & 2.640 & 2.360 & 1.550 \\
\hline
\end{tabular}

Sumber: Data sekunder diolah (2019)

Berdasarkan tabel 3, PTPP memiliki harga saham tertinggi sebesar Rp 3.810 pada tahun 2015 sedangkan DGIK memiliki harga saham terendah senilai Rp55 pada tahun 2016. Rata-rata harga saham tertinggi selama tahun 2012-2017 dimiliki oleh PTPP sebesar Rp 2.680 sedangkan rata-rata terendah oleh DGIK sebesar Rp58.

\section{Uji Asumsi Klasik}

\section{Uji Normalitas}

Uji ini bertujuan untuk menguji apakah nilai residual dalam model regresi panel berdistribusi normal atau tidak. Pengujian ini menggunakan uji KolmogorovSmirnove (Uji K-S) dengan kriteria jika angka sig. uji K-S > 0,05 maka data residual dikatakan terdistribusi normal, jika angka sig. uji $\mathrm{K}-\mathrm{S} \leq 0,05$ maka data tidak berdistribusi normal. Hasil uji normalitas ada di tabel 4 berikut ini :

Tabel 4. Hasil Uji Nomalitas

\begin{tabular}{lllll}
\hline Variabel & $\mathrm{N}$ & Sig & Std & Keterangan \\
\hline $\begin{array}{l}\text { Unstandardized } \\
\text { residual }\end{array}$ & 35 & 0,200 & $>0,05$ & $\begin{array}{l}\text { Berdistribusi } \\
\text { Normal }\end{array}$ \\
\hline
\end{tabular}

Sumber: Data sekunder diolah, 2019 
Hasil pada tabel 4 menunjukkan bahwa data residual berdistribusi normal karena nilai Asymp. sig. > 0,05. Hal ini terjadi setelah dilakukan transformasi data ke dalam bentuk Ln pada setiap variabel DAR, NPM dan Harga Saham. Ln atau logaritma natural yaitu logaritma dengan bilang dasar e, dimana e= 2,718 (Gujarati, 2003, p. 49). Oleh karena itu, semua pengujian dalam penelitian ini akan menggunakan data yang sudah ditransformasi dalam bentuk ln.

\section{Uji Multikolinieritas}

Adanya korelasi antara variabel independen dalam satu regresi disebut dengan multikolinieritas, untuk mendeteksi multikolinieritas, yaitu dengan melihat nilai tolerance value atau Variance Inflation Factor (VIF) dengan kriteria jika tolerance value $>0,1$ dan $\mathrm{VIF}<10$, maka disimpulkan tidak terjadi gejala multikolinearitas dan jika tolerance value $\leq 0,1$ dan VIF $>10$, maka disimpulkan terjadi gejala multikolinearitas antar variabel pada model regresi.

Tabel 5. Hasil Uji Multikolinearitas

\begin{tabular}{llllll}
\hline Variabel & VIF & Std & Tolerance & Std & Keterangan \\
\hline Ln_DAR & 1,043 & $<10$ & 0,958 & $>0,1$ & Tidak terjadi multikolinearitas \\
Ln_NPM & 1,043 & $<10$ & 0,958 & $>0,1$ & Tidak terjadi multikolinearitas
\end{tabular}

Sumber: Data Hasil Penelitian Periode Tahun 2012-2017 yang telah diolah

Berdasarkan tabel 5, dapat diketahui bahwa nilai VIF pada variabel DAR dan NPM = $1,043<10$ serta tolerance value variabel DAR dan NPM=0,958 > 0,1. Dengan demikian dapat disimpulkan bahwa tidak terjadi gejala multikolinearitas pada variabel-variabel tersebut.

\section{Uji Heteroskedastisitas}

Uji heteroskedastisitas digunakan untuk melihat apakah terdapat ketidaksamaan varians dari residual satu pengamatan ke pengamatan lain. Sebuah model persamaan dapat dikatakan tidak mengalami gangguan heteroskedastisitas apabila titik-titik pada grafik scatterplot menyebar secara merata dan tidak membentuk pola tertentu atau mengumpul di satu titik tertentu. 


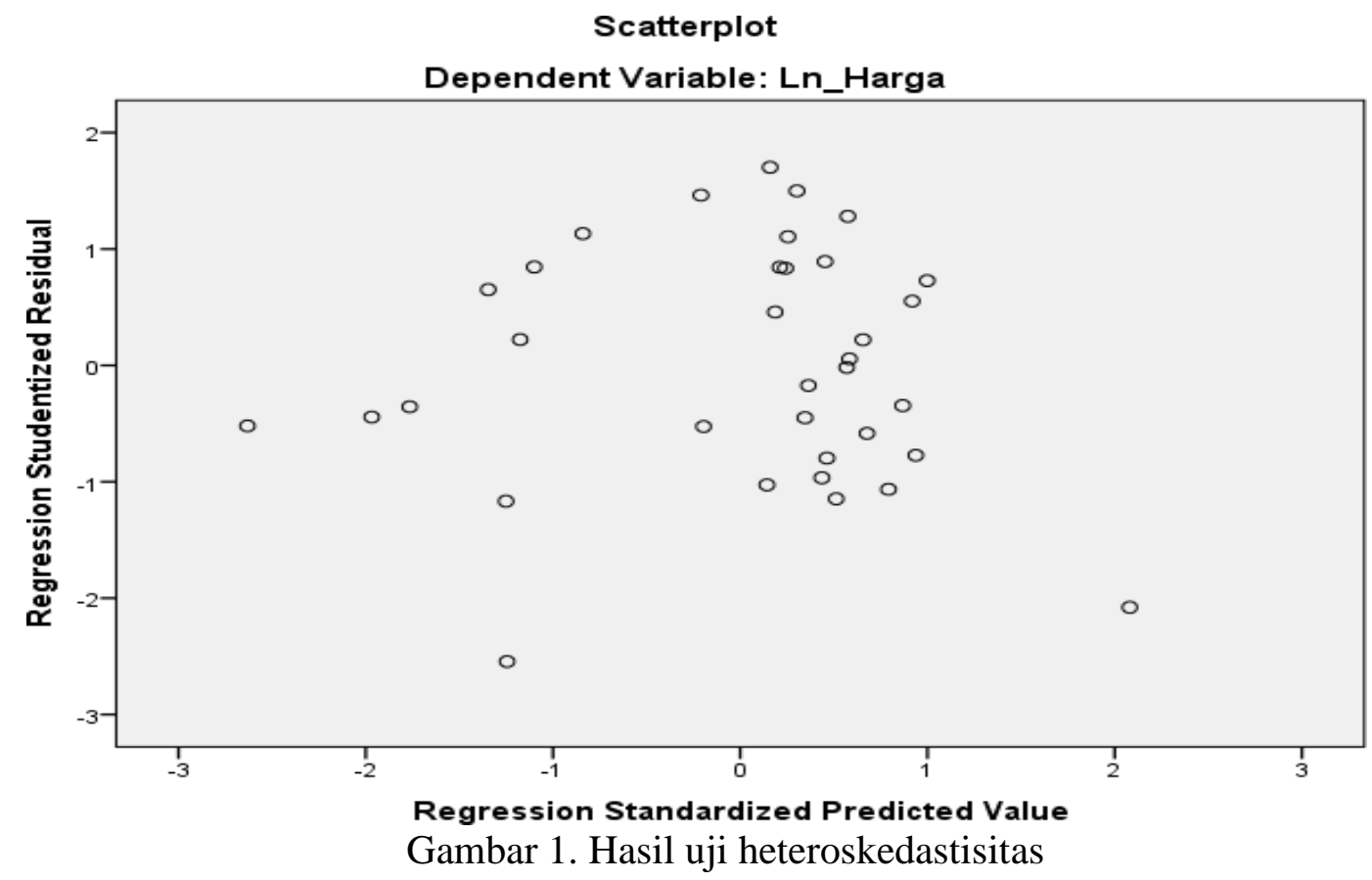

Berdasarkan gambar 1 dapat disimpulkan bahwa tidak mengalami gangguan heteroskedastisitas karena titik-titik pada grafik scatterplot menyebar secara merata dan tidak membentuk pola tertentu.

\section{Uji Autokorelasi}

Pengujian ini dimaksudkan untuk melihat adanya hubungan data satu dengan data yang lainnya dalam satu variabel. Pengambilan keputusan ada tidaknya autokorelasi adalah bila nilai DW terletak antara batas atas atau upper bound (du) dan (4-du) maka koefisien autokorelasinya sama dengan nol, berarti tidak ada autokorelasi.

Tabel 6. Hasil Uji Autokorelasi

\begin{tabular}{llrrrr}
\hline & & \multicolumn{2}{c}{ Adjusted } & \multicolumn{2}{c}{ Std. Error of } \\
Model & R & R Square & R Square & the Estimate & Durbin-Watson \\
\hline 1 &, $740^{\mathrm{a}}$ &, 547 &, 519 &, 75316 & 1,834 \\
\hline
\end{tabular}

Berdasarkan tabel 6, nilai Durbin Watson (DW) sebesar 1,834. Nilai DU sebesar 1,587 dicari pada tabel durbin watson pada signifikansi 0,05 dengan $n=36$. Nilai DW 1,834 lebih besar dari batas atas (du) yakni 1,587 $(1,834>1,587)$ dan lebih kecil dari (4-du) 4-1,587=2,413. Karena itu, dapat disimpulkan bahwa tidak terdapat autokorelasi. 


\section{Uji Linearitas}

Uji linearitas digunakan untuk mengetahui apakah dua variabel mempunyai hubungan yang linear atau tidak secara signifikan. Linearitas biasanya digunakan sebagai prasyarat dalam analisis korelasi atau regresi linear. Penelitian ini menggunakan korelasi untuk memberikan informasi mengenai hubungan antar variabel, diperoleh hasil sebagai berikut:

Tabel 7. Hasil Uji Linearitas

\begin{tabular}{llrrr}
\hline & & Ln_Harga & Ln_DAR & Ln_NPM \\
\hline Pearson Correlation & Ln_Harga & 1,000 &, 686 &, 410 \\
\cline { 2 - 5 } & Ln_DAR &, 686 & 1,000 &, 204 \\
\cline { 2 - 5 } & Ln_NPM &, 410 &, 204 & 1,000 \\
\hline \multirow{2}{*}{ Sig. (1-tailed) } & Ln_Harga &. &, 000 &, 007 \\
\cline { 2 - 5 } & Ln_DAR &, 000 &. &, 120 \\
\cline { 2 - 5 } & Ln_NPM &, 007 &, 120 & \\
\hline N & Ln_Harga & 35 & 35 & 35 \\
\cline { 2 - 5 } & Ln_DAR & 35 & 35 & 35 \\
\cline { 2 - 5 } & Ln_NPM & 35 & 35 & 35 \\
\hline
\end{tabular}

Sumber: Data Hasil Penelitian Periode Tahun 2012-2017 yang telah diolah

Berdasarkan tabel 7, dapat disimpulkan bahwa hubungan antara variabel DAR dan variabel harga signifikan jika dilihat angka signifikansi (sig) sebesar 0,000 yang lebih kecil dari $0,05(0,000<0,05)$. Hubungan antara variabel NPM dan variabel harga juga signifikan jika dilihat angka signifikansi (sig) sebesar 0,007 yang lebih kecil dari $0,05(0,007<0,05)$. 


\section{Analisis Data}

\section{Uji Regresi Data Panel}

Berikut ini adalah hasil perhitungan regresi data panel untuk debt to asset ratio, net profit margin dan harga saham menggunakan SPSS 24:

Tabel 8. Hasil Uji Regresi Data Panel

\begin{tabular}{|c|c|c|c|c|c|c|c|}
\hline \multirow[b]{2}{*}{ Model } & & \multicolumn{2}{|c|}{ Unstandardized Coefficients } & \multirow{2}{*}{$\begin{array}{c}\text { Standardized } \\
\text { Coefficients } \\
\text { Beta }\end{array}$} & & \multirow[b]{2}{*}{$\mathrm{t}$} & \multirow[b]{2}{*}{ Sig. } \\
\hline & & B & Std. Error & & & & \\
\hline \multirow{3}{*}{1} & (Constant) & 9,459 &, 517 & & & 18,290 &, 000 \\
\hline & Ln_DAR & 3,491 & 675 & & 629 & 5,174 & ,000 \\
\hline & Ln_NPM & ,374 & ,161 & & ,282 & 2,318 & ,027 \\
\hline
\end{tabular}

a. Dependent Variable: Ln

Sumber: Data Hasil Penelitian Periode Tahun 2012-2017 yang telah diolah

Semua variabel dalam penelitian ini diolah dengan transformasi Ln supaya mendapatkan data residual berdistribusi normal sehingga memberikan pengaruh pada persamaan regresi data panel. Sebelum setiap variabel dilakukan tranformasi data dengan Ln, peneliti menggunakan persamaan regresi data panel sebagai berikut:

Yit $=\alpha+b 1 X 1$ it $+b 2 X 2 i t+e$

Dimana:

$\mathrm{Y}=$ Harga saham

$\mathrm{X} 1$ = Debt to Asset Ratio

$\mathrm{X} 2=$ Net profit margin

Setelah setiap variabel ditransformasi dalam bentuk Ln, maka persamaan yang digunakan dalam penelitian ini yaitu Model Elastisitas-Konstan. Berikut persamaan Model Elastisitas-Konstan menurut Gujarati (2003, p. 49):

$\mathrm{Yi}=\beta_{0} \mathrm{X}_{1}{ }^{\beta 1} \mathrm{e}^{\mathrm{ui}}$, yang secara alternatif bisa dinyatakan sebagai berikut:

$\mathrm{LnY}=\alpha+\beta_{1} \mathrm{~L}_{\mathrm{n}} \mathrm{X}_{1}+\beta_{2} \mathrm{~L}_{\mathrm{n}} \mathrm{X}_{2}$

Model persamaan tersebut disebut model log-ganda. Model log-ganda adalah koefisien kemiringan $\beta 1$ mengukur elastisitas, yaitu persentase perubahan dalam (\%) $\mathrm{Y}$ akibat perubahan dalam (\%) $\mathrm{X}$ atau $\mathrm{X}$ (variabel bebas) mempengaruhi $\mathrm{Y}$ (variabel terikat) (Gujarati, 2003, p. 49). Dari hasil analisis regresi data panel yang disajikan pada tabel 8, maka diperoleh persamaan regresi sebagai berikut: 
$\operatorname{LnY}=9,459+3,491 \operatorname{LnX} 1+0,374 \operatorname{LnX} 2$

Koefisien regresi DAR dan NPM dimaknai sebagai elastisitas, maka persamaannya sebagai berikut:

$\mathrm{Y}=12.823,05 \mathrm{X}_{1}^{3,491} \cdot \mathrm{X}_{2}{ }^{0,374}$

\section{Uji Hipotesis}

\section{Uji F}

Uji F digunakan untuk melakukan uji hipotesis koefisien (slope) regresi secara bersamaan. Berikut hasil uji F yang diperoleh:

\section{Tabel 9. Hasil Uji F}

\section{ANOVA}

\begin{tabular}{|c|c|c|c|c|c|c|}
\hline \multicolumn{2}{|c|}{ Model } & \multirow{2}{*}{$\begin{array}{r}\begin{array}{c}\text { Sum of } \\
\text { Squares }\end{array} \\
21,924 \\
\end{array}$} & \multirow{2}{*}{$\frac{\mathrm{df}}{2}$} & \multirow{2}{*}{$\begin{array}{c}\begin{array}{c}\text { Mean } \\
\text { Square }\end{array} \\
10,962 \\
\end{array}$} & \multirow{2}{*}{$\begin{array}{c}\mathrm{F} \\
19,324 \\
\end{array}$} & \multirow{2}{*}{$\begin{array}{l}\text { Sig. } \\
\quad, 000^{\mathrm{b}}\end{array}$} \\
\hline 1 & Regression & & & & & \\
\hline & Residual & 18,152 & 32 &, 567 & & \\
\hline & Total & 40,076 & 34 & & & \\
\hline
\end{tabular}
a. Dependent Variable: Ln_Harga
b. Predictors: (Constant), Ln_NPM, Ln_DAR

Sumber: Data Hasil Penelitian Periode Tahun 2012-2017 yang telah diolah

Langkah-langkah uji $\mathrm{F}$ adalah :

a. Menetapkan hipotesis nol $\left(\mathrm{H}_{0}\right)$ dan hipotesis alternatif $\left(\mathrm{H}_{1} / \mathrm{H}_{\mathrm{a}}\right)$

$\mathrm{H}_{0}: \beta_{1}=\beta_{2}=0$ artinya, solvabilitas dan profitabilitas secara bersama-sama tidak berpengaruh terhadap harga saham.

$\mathrm{H}_{\mathrm{a}}$ : tidak semua $\beta_{i} \neq 0$ artinya, solvabilitas dan profitabilitas secara bersama-sama berpengaruh terhadap harga saham.

b. Memilih tingkat signifikansi $(\alpha)$

Tingkat signifikansi yang digunakan dalam penelitian ini yaitu $\alpha=0,05$.

c. Menghitung F statistik (Fhitung)

Nilai Fhitung diperoleh dari output SPSS sebesar 19,324 dan Ftabel dicari pada tabel statistik pada signifikansi 0,05 dengan $n-k=34$, didapat nilai Ftabel sebesar 3,28 . 
d. Merumuskan kaidah keputusan

Ho diterima dan Ha ditolak terjadi, jika Fhitung $\leq$ Ftabel

Ho ditolak dan Ha diterima terjadi, jika Fhitung > Ftabel

e. Mengambil Kesimpulan

Berdasarkan tabel 9, nilai Fhitung yang diperoleh sebesar 19,324 lebih besar dari nilai Ftabel sebesar 3,28 (19,324> 3,28) sehingga Ho ditolak dan Ha diterima yang artinya solvabilitas dan profitabilitas secara bersama-sama berpengaruh terhadap harga saham.

\section{Uji t}

Uji t digunakan untuk menguji koefisien regresi secara individu atau parsial disetiap variabel bebas terhadap variabel terikat. Berikut hasil uji t yang diperoleh:

Tabel 10. Hasil Uji t

\begin{tabular}{|c|c|c|c|c|c|c|}
\hline \multicolumn{7}{|c|}{ Coefficients $^{\mathrm{a}}$} \\
\hline \multirow[b]{2}{*}{$\begin{array}{l}\text { Mod } \\
\text { el }\end{array}$} & & \multicolumn{2}{|c|}{$\begin{array}{l}\text { Unstandardized } \\
\text { Coefficients }\end{array}$} & $\begin{array}{r}\text { Standardized } \\
\text { Coefficients }\end{array}$ & \multirow[b]{2}{*}{$\mathrm{t}$} & \multirow[b]{2}{*}{ Sig. } \\
\hline & & B & Std. Error & Beta & & \\
\hline \multirow[t]{3}{*}{1} & (Constant) & 9,459 & ,517 & & $\begin{array}{r}18,29 \\
0 \\
\end{array}$ & , 000 \\
\hline & Ln_DAR & 3,491 & ,675 & ,629 & 5,174 &, 000 \\
\hline & Ln_NPM & ,374 &, 161 & ,282 & 2,318 &, 027 \\
\hline
\end{tabular}

a. Dependent Variable: Ln_Harga

Sumber: Data Hasil Penelitian Periode Tahun 2012-2017 yang telah diolah

Langkah-langkah uji t adalah:

a. Variabel Debt to Asset Ratio (DAR)

1) Menetapkan Hipotesis $\mathrm{Nol}\left(\mathrm{H}_{0}\right)$ dan Hipotesis Alternatif $\left(\mathrm{H}_{1} / \mathrm{H}_{\mathrm{a}}\right)$

Adapun hipotesis penelitian ini sebagai berikut:

$\mathrm{H}_{01}: \beta_{1}=0$ artinya, solvabilitas secara parsial tidak berpengaruh terhadap harga saham.

$\mathrm{H}_{\mathrm{a} 1}: \beta_{1} \neq 0$ artinya, solvabilitas secara parsial berpengaruh terhadap harga saham.

2) Memilih Tingkat Signifikansi $(\alpha)$

Tingkat signifikansi yang digunakan dalam penelitian ini yaitu $\alpha=0,05$.

3) Menghitung t statistik 
Nilai t hitung diperoleh dari output SPSS adalah 5,174 dan t tabel dicari pada tabel statistik pada signifikansi 0,05 dengan $\mathrm{n}-\mathrm{k}-1=33$ di dapat nilai $\mathrm{t}$ tabel sebesar 2,03452.

4) Merumuskan kaidah keputusan

Ho ditolak dan Ha diterima jika $-\mathrm{t}$ tabel $>\mathrm{t}$ hitung $>\mathrm{t}$ tabel atau sig. $<0,05$.

Ho diterima dan Ha ditolak jika $-\mathrm{t}$ tabel $\leq \mathrm{t}$ hitung $\leq \mathrm{t}$ tabel atau sig. $\geq 0,05$.

5) Mengambil kesimpulan

Berdasarkan tabel 10, dapat dilihat bahwa nilai t hitung variabel DAR sebesar 5,174 lebih besar dari nilai t tabel yaitu sebesar 2,03452 (5,174> 2,03452). Uji t pada variabel DAR dengan nilai signifikansi lebih kecil dari 0,05 yaitu 0,000 $(0,000<0,05)$ maka Ho ditolak dan Ha diterima yang berarti solvabilitas berpengaruh secara parsial terhadap harga saham.

b. Variabel Net Profit Margin (NPM)

1) Menetapkan Hipotesis Nol (Ho) dan Hipotesis Alternatif (H1 / Ha)

$\mathrm{H}_{02}: \beta_{2}=0$ artinya, profitabilitas secara parsial tidak berpengaruh terhadap harga saham.

$\mathrm{H}_{\mathrm{a} 2}: \beta_{2} \neq 0$ artinya, profitabilitas secara parsial berpengaruh terhadap harga saham.

2) Memilih Tingkat Signifikansi $(\alpha)$

Tingkat signifikansi yang digunakan dalam penelitian ini yaitu $\alpha=0,05$.

3) Menghitung t statistik

Nilai $\mathrm{t}$ hitung diperoleh dari output SPSS adalah 2,318 dan t tabel dicari pada tabel statistik pada signifikansi 0,05 dengan $n-k-1=33$ di dapat nilai $\mathrm{t}$ tabel sebesar 2,03452.

4) Merumuskan kaidah keputusan

Ho ditolak dan Ha diterima jika $-\mathrm{t}$ tabel $>\mathrm{t}$ hitung $>\mathrm{t}$ tabel atau sig. $<0,05$.

Ho diterima dan Ha ditolak jika $-\mathrm{t}$ tabel $\leq \mathrm{t}$ hitung $\leq \mathrm{t}$ tabel atau sig. $\geq 0,05$.

5) Mengambil kesimpulan

Berdasarkan tabel 10, dapat dilihat bahwa nilai t hitung variabel NPM sebesar 2,318 lebih besar dari t tabel yaitu sebesar 2,03452 (2,318> 2,03452). Uji t pada variabel NPM dengan nilai signifikansi lebih kecil dari 0,05 yaitu $0,027(0,027<$ 
0,05) maka, Ho ditolak dan Ha diterima. Ini berarti profitabilitas berpengaruh secara parsial terhadap harga saham.

\section{Koefisien Determinasi $\left(R^{2}\right)$}

Menurut Ghozali (2011, p. 97) koefisien determinasi $\left(\mathrm{R}^{2}\right)$ digunakan untuk mengukur seberapa jauh kemampuan model dalam menerangkan variasi variabel dependen. Suatu model dikatakan baik jika memiliki $\mathrm{R}^{2}$ yang besar (mendekati 1). Nilai $\mathrm{R}^{2}$ yang kecil berarti kemampuan variabel-variabel independen dalam menjelaskan variasi variabel dependen amat terbatas.

Tabel 11. Hasil Perhitungan Koefisien Determinasi

\begin{tabular}{ccccc}
\hline Model & $\mathrm{R}$ & $\begin{array}{c}\mathrm{R} \\
\text { Square }\end{array}$ & $\begin{array}{c}\text { Adjusted } \mathrm{R} \\
\text { Square }\end{array}$ & $\begin{array}{c}\text { Std. Error of } \\
\text { the Estimate }\end{array}$ \\
\hline 1 & $0,740^{\mathrm{a}}$ & 0,547 & 0,519 & 0,75316
\end{tabular}

Sumber: Data Hasil Penelitian Periode Tahun 2012-2017 yang telah diolah

Dari hasil koefisien determinasi yang disajikan pada tabel 11 dapat dilihat bahwa besarnya Adjusted $R^{2}$ adalah $0,519=51,9 \%$. Ini berarti variasi dalam harga saham dapat dijelaskan oleh variasi dalam variabel solvabilitas yaitu Debt to Asset Ratio (DAR) dan profitabilitas yaitu Net Profit Margin(NPM) sebesar 51,9\%. Sedangkan nilai eror terms (e/C) yang merupakan elemen variasi variabel dependen yang tidak dapat dijelaskan oleh semua variabel independent adalah sebesar $\varepsilon=$ $\sqrt{1-R^{2}}=\sqrt{1-0,519}=0,6935$

\section{Pembahasan Hasil Penelitian}

\section{Pengaruh Solvabilitas terhadap Harga Saham}

Solvabilitas adalah kemampuan suatu perusahaan untuk memenuhi kewajibannya dalam membayar utang secara tepat waktu. Penelitian ini menggunakan Debt to Asset Rasio (DAR) sebagai rasio utang untuk mengukur perbandingan antara total utang dengan total aktiva (Kasmir, 2012, p. 156). Dengan kata lain, seberapa besar utang perusahaan berpengaruh terhadap pengelolaan aktiva. Angka rasio DAR yang tinggi menunjukkan proporsi modal sendiri yang rendah 
untuk membiayai aktiva. Hal ini akan direspon negatif oleh para investor di pasar modal.

Jika DAR berpengaruh terhadap harga saham berarti semakin tinggi angka DAR maka semakin rendah harga saham, dan sebaliknya. Namun, berdasarkan hasil pengujian pada penelitian ini ditemukan bahwa semakin tinggi angka DAR maka semakin tinggi harga saham, karena koefisien regresi yang bernilai positif $(+)$ yaitu sebesar 3,491. Koefisien regresi DAR yang dimaknai sebagai elastisitas bernilai 3,491 artinya jika variabel DAR mengalami kenaikan 1\% maka harga saham akan mengalami peningkatan sebesar 3,491\% dengan asumsi angka NPM tetap.

Hasil penelitian ini menunjukkan bahwa solvabilitas dapat menjadi salah satu pertimbangan investor dalam pengambilan keputusan untuk melakukan investasi. Penelitian dilakukan pada perusahaan jasa sub sektor konstruksi bangunan yang cenderung membutuhkan aktiva yang besar untuk mendorong kegiatan operasional jangka panjang perusahaan agar perusahaan dapat mempertahankan kelangsungan bisnisnya. Aktiva tersebut didapat perusahaan dengan cara melakukan pinjaman atau utang. Maka dari itu, ketika angka DAR tinggi maka akan semakin tinggi harga saham perusahaan.

Berdasarkan tabel 1 diketahui bahwa rata-rata DAR setiap perusahaan selama tahun 2012-2017 berkisar mulai dari 49\% - 79\% sehingga masih berada di bawah $100 \%$ (<100\%). Hal ini menandakan bahwa masih dimungkinkan apabila perusahaan ingin melakukan pinjaman untuk mendapatkan aktiva yang akan digunakan untuk mengembangkan usaha. Maka dari itu, solvabilitas dan harga saham memiliki hubungan yang positif karena perusahaan menggunakan utang untuk memperoleh aktiva yang digunakan untuk kegiatan operasional jangka panjang perusahaan sehingga ketika angka DAR tinggi harga saham juga akan semakin tinggi.

DAR berpengaruh positif (+) terhadap harga saham terjadi karena strategi perusahaan dalam pendanaan terkait dengan struktur modal yaitu teori trade-off. Menurut Brigham dan Houston (2010, p. 183), teori trade-off adalah teori struktur modal dimana penggunaan utang dalam jumlah besar, dapat mengurangi pajak dan menyebabkan semakin banyak laba operasi perusahaan yang mengalir kepada investor. Menurut Syahyunan (2013, p. 228) perusahaan dengan tingkat profitabilitas yang tinggi akan berusaha mengurangi pajaknya dengan cara meningkatkan rasio 
hutangnya sehingga teori trade-off menyeimbangkan manfaat dan pengorbanan yang timbul sebagai akibat penggunaan hutang. Bila manfaat yang diperoleh lebih besar maka tambahan utang masih diperkenankan, dalam hal ini karena range angka DAR kurang dari $100 \%(<100 \%)$. Apabila pengorbanan karena penggunaan hutang sudah lebih besar, maka tambahan hutang sudah tidak diperbolehkan. Berdasarkan teori trade-off, nilai perusahaan akan semakin meningkat seiring dengan meningkatnya tingkat hutang.

Hasil penelitian ini bertentangan dengan hasil penelitian yang dilakukan oleh Khoir et al. (2013) yang menyatakan ada pengaruh negatif dan tidak signifikan dari DAR terhadap harga saham. Salah satu alasannya adalah adanya perbedaan jenis sektor perusahaan yang diteliti saat ini dengan penelitian terdahulu. Hal ini karena setiap jenis sektor atau subsektor perusahaan di BEI memiliki komposisi yang berbeda, baik ukuran perusahaan ataupun jenis perusahaannya.

Solvabilitas menjadi pertimbangan investor dalam memilih harga saham perusahaan sebab solvabilitas yang diproksi dengan rasio DAR berpengaruh positif terhadap harga saham yang artinya, semakin tinggi angka DAR maka semakin tinggi harga saham perusahaan jasa sub sektor konstruksi bangunan yang tidak sesuai dengan teori DAR dimana ketika angka DAR naik harga saham akan turun. Hal ini dapat terjadi dikarenakan beberapa faktor tertentu, yaitu:

a. Sampel penelitian yang digunakan oleh peneliti yaitu enam perusahaan jasa sub sektor konstruksi bangunan yang melakukan go public selambat-lambatnya tahun 2010. Hal tersebut menunjukkan bahwa enam perusahaan tersebut sudah lebih dari delapan tahun berdiri dan menjalankan kegiatan bisnisnya. Dengan fakta tersebut, enam perusahaan yang diteliti sudah dipercaya investor dan tentunya sudah memiliki pengalaman dalam menjalankan bisnis di sektor konstruksi bangunan. Ketika perusahaan memiliki utang yang tinggi, investor yakin bahwa utang tersebut digunakan untuk mengembangkan usaha yang bersifat jangka panjang, yang kemudian akan menghasilkan keuntungan. Jadi, meskipun angka DAR tinggi, tetapi laba yang mengalir kepada investor tetap tinggi yang menyebabkan harga saham juga akan semakin tinggi. Oleh karena itu, investor tertarik untuk memperhatikan solvabilitas yang diproksi dengan rasio DAR. 
b. Kurang lebih dalam lima tahun terakhir, pemerintah Indonesia sedang gencargencarnya melakukan pembangunan di berbagai daerah di Indonesia mulai dari jalan tol hingga fasilitas publik lainnya. Ketika aktivitas keterlibatan perusahaan jasa sub sektor konstruksi bangunan dalam melakukan pembangunan semakin tinggi, hal ini menunjukkan bahwa bisnis tersebut sudah mampu menembus pasar yang ditargetkan untuk memenuhi permintaan. Alhasil wujud pembangunan dari sektor tersebut akan tampak di kalangan para investor. Imbasnya, tingkat kepercayaan investor akan turut meningkat dalam perkembangan sektor ini. Jadi, meskipun angka DAR tinggi tetapi investor lebih mempertimbangkan perkembangan industri sehingga permintaan saham akan menaik dan berpengaruh terhadap harga saham yang tinggi pula. Maka, investor mempertimbangkan solvabilitas dalam memilih obyek investasi.

\section{Pengaruh Profitabilitas terhadap Harga Saham}

Variabel NPM memiliki nilai t hitung sebesar 2,318 yang lebih besar dari t tabel yaitu sebesar 2,03452 $(2,318>2,03452)$ dan nilai signifikansi lebih kecil dari 0,05 yaitu $0,027(0,027<0,05)$. Hal ini memiliki arti bahwa NPM berpengaruh terhadap harga saham. Profitabilitas adalah kemampuan perusahaan dalam menghasilkan laba. Penelitian ini menggunakan Net Profit Margin (NPM) sebagai rasio profitabilitas untuk mengukur kemampuan perusahaan dalam rangka memberikan return kepada pemegang saham (Prihadi, 2013, p. 147).

Menurut teori, NPM memiliki pengaruh positif (+) terhadap harga saham. Ini berarti semakin tinggi angka NPM, maka semakin tinggi pula harga sahamnya. Pada penelitian yang dilakukan oleh Khoir et al. (2013) dan Husaini (2012) didapatkan bahwa NPM berpengaruh tidak signifikan terhadap harga saham. Hasil penelitian ini selaras dengan Suwandani et al. (2017) dan Hutami (2012) yaitu NPM berpengaruh terhadap harga saham. Hal tersebut berarti peningkatan atau penurunan angka net profit margin akan memberikan dampak terhadap harga saham. NPM berpengaruh terhadap harga saham menunjukkan bahwa investor cenderung dapat memperhatikan NPM sebagai rasio yang dapat dipertimbangkan dalam keputusan investasi mereka. Hal ini juga menunjukkan bahwa investor mempertimbangkan kemampuan perusahaan dalam mengelola efisiensi kinerja operasionalnya. 
Nilai koefisien regresi sebesar 0,374, artinya jika variable NPM mengalami kenaikan $1 \%$ maka harga saham akan mengalami peningkatan sebesar $0,374 \%$ dengan asumsi angka DAR tetap. Koefisien regresi NPM yang dimaknai sebagai elastisitas bernilai positif artinya ada hubungan searah antara NPM dengan harga saham. Koefisien NPM yang positif ini berarti ketika angka NPM naik maka harga saham akan naik. Hasil penelitian ini menunjukkan bahwa profitabilitas yang diproksi dengan rasio NPM dapat menjadi salah satu pertimbangan investor dalam pengambilan keputusan untuk melakukan investasi.

Berdasarkan tabel 2 tentang rekapitulasi data net profit margin, NPM perusahaan jasa sub sektor kontruksi bangunan mengalami fluktuasi namun, rata-rata memiliki angka NPM yang positif. Walaupun begitu, terdapat perusahaan yang memiliki NPM negatif seperti yang terjadi pada perusahaan PT Nusa Konstruksi Enjiniring Tbk (DGIK) yang memiliki angka NPM negatif pada tahun 2016 yaitu $34,9 \%$. Namun, perusahaan kembali bisa memperoleh angka NPM positif di tahun berikutnya yang menunjukkan ada upaya perusahaan dalam meningkatkan kembali laba perusahaan. Pada tahun 2017, perusahaan menerima kontrak proyek baru seperti proyek gedung perkantoran World Capital Tower dan Holland Village di Jakarta, serta pengembangan jalan di Sumatera dan Sulawesi. Hal tersebut dapat menjadi pertimbangan investor untuk menggunakan NPM dalam memilih obyek investasinya, sebab dari hasil penelitian enam perusahaan tersebut memiliki kinerja yang baik berdasarkan rasio net profit margin.

\section{Kesimpulan, Implikasi, Saran dan Keterbatasan}

Kesimpulan dalam penelitian ini adalah solvabilitas yang diproksi dengan rasio Debt to Asset Ratio (DAR) dan profitabilitas yang diproksi dengan rasio $\mathrm{Net}$ Profit Margin (NPM) secara parsial berpengaruh terhadap harga saham.

Saran dalam penelitian ini diberikan kepada investor maupun calon investor dan peneliti selanjutnya. Sebagai investor maupun calon investor yang akan membeli saham perusahaan konstruksi bangunan sebaiknya memperhatikan Debt to Assets Ratio (DAR) dan Net Profit Margin (NPM) sebab rasio tersebut berpengaruh terhadap harga saham. Semakin tinggi angka DAR dan NPM, maka semakin tinggi harga saham, namun investor juga harus tetap memperhatikan batas aman angka DAR yaitu $<100 \%$. Peneliti selanjutnya dapat menggunakan rasio solvabilitas dan 
profitabilitas selain DAR dan NPM sehingga dapat memberikan hasil yang berbeda dari penelitian ini. Peneliti selanjutnya juga dapat menggunakan faktor eksternal yang mempengaruhi harga saham seperti kebijakan pemerintah, inflasi, tingkat bunga dan lain-lain, sehingga informasi yang dikumpulkan oleh investor dan calon investor lebih lengkap.

Penelitian ini mempunyai dua keterbatasan. Pertama, hanya menggunakan dua variabel independen yaitu solvabilitas dan profitabilitas yang masing-masing diproksi dengan rasio Debt to Asset Ratio (DAR) dan Net Profit Margin (NPM) sehingga hasil penelitian tidak mencerminkan kondisi perusahaan jasa sub sektor konstruksi bangunan secara menyeluruh. Kedua, jumlah sampel yang digunakan hanya sebanyak enam perusahaan jasa sub sektor konstruksi bangunan dalam rentang waktu enam tahun, yaitu dimulai pada tahun 2012 dan diakhiri pada tahun 2017. Hal tersebut menyebabkan informasi yang dikumpulkan kurang lengkap sehingga hasil dari penelitian ini kurang mencerminkan kondisi perusahaan jasa sub sektor kontruksi bangunan secara menyeluruh.

\section{Referensi}

Brigham dan Houston. (2010). Dasar-dasar Manajemen Keuangan Buku 1. Salemba Empat: Jakarta.

Fahmi, I. (2011). Analisa Laporan Keuangan. Alfabeta : Bandung.

Fahmi, I. (2013). Pengantar Manajemen Keuangan. Alfabeta : Bandung.

Fahmi, I. (2014). Manajemen Keuangan Perusahaan dan Pasar Modal. Mitra Wacana Media : Jakarta.

Fraser, L. M. \& A. O. (2001). Memahami Laporan Keuangan. PT Intan Sejati Klaten : Jakarta.

Ghozali, I. (2011). Aplikasi Analisis Multivariate Dengan Program SPSS. Badan Penerbit Universitas Diponegoro : Semarang.

Gujarati, D. (2003). Ekonometrika Dasar. Erlangga : Jakarta.

Husaini, A. (2012). Pengaruh Variabel Return On Assets, Return On Equity, Net Profit Margin Dan Earning Per Share Terhadap Harga Saham Perusahaan. Profit: Jurnal Administrasi Bisnis, 6(1), 45-49.

Hutami, R. P. (2012). Pengaruh Dividend Per Share, Return On Equity Dan Net Profit Margin Terhadap Harga Saham Perusahaaan Industri Manufaktur Yang Tercatat Di Bursa Efek Indonesia Periode 2006-2010. Nominal: Barometer Riset Akuntansi Dan Manajemen, 1(2), 104-123.

Indonesia, U. R. (1995). Undang-undang Pasar Modal No. 8 Tahun 1995 tentang Reksa Dana. Jakarta.

Kasmir. (2012). Analisis Laporan Keuangan. PT RajaGrafindo Persada : Jakarta.

Khoir, V. B. (2013). Pengaruh Earning Per Share, Return On Assets, Net Profit Margin, Debt To Assets Ratio Dan Long Term Debt To Equity Ratio Terhadap 
Harga Saham (Studi Pada Perusahaan Subsektor Perdagangan yang Terdaftar di Bursa Efek Indonesia Periode 2010-2012). Jurnal Administrasi Bisnis, 5(1).

Manoppo, V. C. O. (2017). Pengaruh Current Ratio, DER, ROA dan NPM Terhadap

Harga Saham Pada Perusahaan Food and Beverages yang terdaftar di BEI

(Periode 2013-2015). Jurnal EMBA, 5(2), 1813-1822.

Prihadi, T. (2013). Analisis Laporan keuangan : Teori dan Aplikasi. PPM : Jakarta.

Purnomo, K. (2017). "Sektor Konstruksi Penyumbang Ketiga Pertumbuhan

EkonomiNasional."

https://properti.kompas.com/read/2017/02/10/220000321/sektor.konstruksi.

diakses tanggal 8 September 2018

Samsul, M. (2015). Pasar Modal \& Manajemen Portofolio. Erlangga : Jakarta.

Sanusi, A. (2011). Metodologi Penelitian Bisnis. Salemba Empat : Jakarta.

Sartono, A. (2008). Manajemen Keuangan Teori dan Aplikasi. BPFE : Yogyakarta.

Sitorus, F. Y., \& Hutasoit, P. S. J. K. (2017). The Effect of EPS and Return on BEI IDX using Value Investing from Benjamin Graham. Fundamental Management Journal, 2(1), 16-21.

Subramanyam, K. . (2017). Analisis Laporan Keuangan. Salemba Empat : Jakarta.

Suwandani, A., \& Suhendro, A. W. (2017). Pengaruh Profitabilitas Terhadap Harga Saham Perusahaan Manufaktur Sektor Makanan Dan Minuman Di Bei Tahun 2014-2015. Jurnal Akuntansi Dan Pajak, 18(01).

Syahyunan. (2013). Manajemen Keuangan: Perencanaan, Analisis, dan Pengendalian Keuangan. USU Press : Medan.

Wangarry, A. R., Poputra, A. T., \& Runtu, T. (2016). Pengaruh Tingkat Return on Investment (ROI), Net Profit Margin (NPM), Dan Debt to Equity Ratio (DER) Terhadap Harga Saham Perbankan Di Bursa Efek Indonesia (BEI). Jurnal EMBA: Jurnal Riset Ekonomi, Manajemen, Bisnis Dan Akuntansi, 3(4).

Wardiyah, M. L. (2017). Analisis Laporan Keuangan. Pustaka Setia : Bandung.

Widarjono, A. (2007). Ekonometrika: Teori dan Aplikasi Untuk Ekonomi dan Bisnis (kedua). Ekonisia FE Universitas Islam Indonesia: Yogyakarta.

Wira, D. (2011). Analisis Fundamental Saham. Exceed : Bandung. 